\title{
Plant Beneficial Endophytic Bacteria from the Ethnomedicinal Mussaenda roxburghii (Akshap) of Eastern Himalayan Province, India
}

\author{
Pramod Kumar Pandey, ${ }^{1}$ Ramkrishna Samanta, ${ }^{2}$ and Raj Narain Singh Yadav \\ ${ }^{1}$ Centre for Studies in Biotechnology, Dibrugarh University, Dibrugarh, Assam 786004, India \\ ${ }^{2}$ Department of Life Sciences, Dibrugarh University, Dibrugarh, Assam 786004, India \\ Correspondence should be addressed to Pramod Kumar Pandey; pramod.pandey84@gmail.com
}

Received 16 August 2015; Revised 30 October 2015; Accepted 4 November 2015

Academic Editor: Jesus L. Romalde

Copyright (C) 2015 Pramod Kumar Pandey et al. This is an open access article distributed under the Creative Commons Attribution License, which permits unrestricted use, distribution, and reproduction in any medium, provided the original work is properly cited.

\begin{abstract}
Mussaenda roxburghii are very important ethnomedicinal plant, used for its various applications from the ancient period. The role of their associated plant beneficial endophytic bacteria was evaluated, which were previously untapped. Among the isolates, PAK6 was identified as efficient phosphate solubilizer, quantified by the molybdenum blue method. Four isolates PAK1, PAK2, PAK3, and PAK8 were able to synthesize significant level of IAA in the presence and absence of tryptophan. Isolates PAK1 and PAK9 were able to produce siderophore on CAS agar media, PAK2 and PAK9 were able to produce HCN, and PAK7 and PAK8 were able to grow on N2-free medium. All the isolates were able to produce a moderate level of polysaccharide and tolerate up to $10 \%$ of $\mathrm{NaCl}$. Isolates PAK3, PAK6, PAK7, and PAK8 were able to grow well at pH 5.0 and isolates PAK2, PAK7, and PAK8 were able to tolerate $600 \mu \mathrm{g} \mathrm{mL}{ }^{-1}$ of $\mathrm{Al}^{+3}$, while all the isolates except PAK1 showed a tolerance to $600 \mu \mathrm{g} \mathrm{mL}^{-1}$ of $\mathrm{Mn}^{+2}$ tested. Endophytic bacterial isolates PAK6 and PAK9 were effective against Sclerotinia sclerotiorum and Sclerotium rolfsii.
\end{abstract}

\section{Introduction}

Plants are the potential reservoir of indigenous microbes principally known as endophyte which can reside inside their tissue without giving any external visible symptoms and is responsible for nutrient assimilation and processing, induction of defense system, and synthesis of secondary metabolites [1]. They are reported to function more efficiently in comparison to external bacteria because a ready-made atmosphere is provided for their growth and proliferation. They transfer information via interaction with the host plant and evolved biochemical pathways which results in the production of plant growth regulators, bioactive compounds, possesses the property of allelopathy and provides resistance to diseases. Besides this they also improve the plant's ability to withstand with environmental stresses, increase soil fertility through the phosphate solubilization and nitrogen fixation, indole acetic acid (IAA), and siderophore production, supply essential vitamins to the plants, provide a range of natural products that could be utilized for the potential use in industries and agriculture [2].

The forest rich region is identified as to encompass a source of an enormous, relatively unexplored microbial diversity that seems to have unique genotype and biological systems that may have external applications for the host plant on which they inhabit normally as endophytes.

Akshap (Mussaenda roxburghii) is a perennial shrub that belongs to the family Rubiaceae cultivated in the foothills and moist areas and known for its high level of fiber content and vitamins [3]. The leaves are cooked and served as vegetables. Iridoid and shanzhiol were reported from the aerial part of Mussaenda roxburghii and showed antibacterial activity against the Staphylococcus aureus and Escherichia coli [4]. Roots are useful in jaundice, skin diseases, cuts, wounds, and so forth $[5,6]$. Leaves are utilized to treat bone fractures [7]. Leaf extracts of Mussaenda roxburghii 
were evaluated for preliminary antimicrobial activity against the various pathogenic Gram-positive bacteria and Gramnegative bacteria [8].

Arunachal Pradesh is considered as one of the major biodiversity "hot spots" in the world located in the Eastern Himalayan province. About two-third of the state is covered with forest. Pasighat is the headquarter of East Siang District in the Arunachal Pradesh that lies on the geographical coordinates of $28.0700^{\circ} \mathrm{N}$ and $95.3300^{\circ} \mathrm{E}$ at a level of $155 \mathrm{~m}$ above mean sea level. The area experiences tropical humid climate during summer and dry mild winter. The place is known for receiving the highest rainfall in a single year with average rainfall $4,388.3 \mathrm{~mm}$.

Keeping in the view a study was planned to evaluate the plant beneficial endophytic bacteria isolated from the ethnomedicinal plant Mussaenda roxburghii of biodiversity hot spot Eastern Himalayan province of Arunachal Pradesh, India.

\section{Materials and Methods}

2.1. Isolation and Enumeration of Endophytes. Whole plants of Mussaenda roxburghii were uprooted manually at their preanthesis stage for the isolation of endophytic bacteria and cleaned thoroughly with tap water. The plant parts (leaves, stems, and roots) were rinsed first with tap water and then five times with sterile distilled water (SDW) to remove the soil particles and dust and finally cut into 2 to $5 \mathrm{~cm}$ long pieces. All the plant samples were blotted dry with the help of autoclaved filter paper and then weighed to have a final weight of $3.0 \mathrm{~g}$. Plant samples were surface-sterilized with $70 \%$ ethanol for $1 \mathrm{~min}$ and then with $2 \% \mathrm{NaOCl}$ for $2 \mathrm{~min}$ for leaf and stem while $2 \% \mathrm{NaOCl}$ for $3 \mathrm{~min}$ in root. They were then finally rinsed four times with autoclaved sterile distilled water (SDW) and dried in laminar flow. A $100 \mu \mathrm{L}$ aliquot from the final wash was inoculated on nutrient agar (NA) media by the pour plate method to confirm sterility. Sterilization process was considered successful and further process of endophyte isolation was continued if no growth was observed on the plate after incubation otherwise the complete process of surface sterilization was repeated. After successful sterilization about $1.0 \mathrm{~g}$ samples of leaf/stem/root are separately macerated under aseptic conditions with a sterile mortar and pestle in $9.0 \mathrm{~mL}$ of sterile water and $1.0 \mathrm{~mL}$ of aliquot was serially diluted up to $10^{-7}$ in potassium phosphate buffer. Each sample $(100 \mu \mathrm{L})$ was inoculated on nutrient agar (NA) media by the pour plate method in three replications and incubated at $28 \pm 2^{\circ} \mathrm{C}$. Bacterial colonies appearing on the plates were purified by repeated streak culture. The endophytic bacterial isolates were selected based on distinct colony morphology and growth and maintained on slants. The purified endophytic bacterial isolates with $50 \%$ $(\mathrm{w} / \mathrm{v})$ glycerol in nutrient broth were maintained in deep freezer $\left(-80^{\circ} \mathrm{C}\right)$ for long term storage and in nutrient agar slant at $4^{\circ} \mathrm{C}$ for short term storage.

2.2. Morphological and Biochemical Characterization. Morphological and biochemical characterization such as colonial surface, colony edge, colony elevation, margin, pigmentation, cell shape, Gram reaction, endospore staining, motility, catalase, oxidase, nitrate reduction test, $\mathrm{H}_{2} \mathrm{~S}$ production, indole production, MRVP test, citrate utilization test, ability to ferment carbohydrate, and enzymatic activity of all isolates were performed by adopting standard procedures, tentatively characterized, grouped, and documented.

\subsection{Plant Beneficial Trait}

2.3.1. Phosphate Solubilization. The phosphate solubilization ability of the endophytic bacterial isolates was carried out by using NBRI-BPB agar medium $\left(\mathrm{g} \mathrm{L}^{-1}\right.$; glucose $10, \mathrm{Ca}_{3}\left(\mathrm{PO}_{4}\right)_{3}$ $5, \mathrm{MgSO}_{4} \cdot 7 \mathrm{H}_{2} \mathrm{O} 0.25, \mathrm{MgCl}_{2} \cdot 6 \mathrm{H}_{2} \mathrm{O} 5, \mathrm{KCl} \mathrm{0.2,}\left(\mathrm{NH}_{4}\right)_{2} \mathrm{SO}_{4}$ 0.1 , BPB 0.025, agar 20, and $\mathrm{pH} 7$ ) [9] and Pikovskaya's agar medium procured from Himedia Laboratories Pvt. Ltd., Mumbai, India. Phosphate solubilizing activities were screened by measuring the clearing zone surrounding the developed bacterial colony via calculation of phosphate solubilization index:

$$
\text { Phosphate solubilization index }=\frac{A}{B} \times 100 \text {. }
$$

$A=$ total diameter (colony + halo zone). $B=$ diameter of colony.

Since the plate assay is not considered as a reliable method to screen the effective phosphate solubilizer endophytic isolates, hence, the endophytic isolates were screened in broth medium containing $5 \mathrm{~g} \mathrm{~L}^{-1} \mathrm{Ca}_{3}\left(\mathrm{PO}_{4}\right)_{2}$ as the insoluble $\mathrm{P}$ source. Each of the isolates was inoculated to Pikovskaya broth $(100 \mathrm{~mL})[10]$ and incubated for 14 days at $28^{\circ} \mathrm{C}$. After incubation, the broth cultures were spun at $9000 \mathrm{rpm}$ for $20 \mathrm{~min}$. The supernatant was used for estimation of inorganic phosphorus by the molybdenum blue method [11]. The amount of phosphate released in the flasks after incubation was estimated in comparison with a set of uninoculated controls. $1 \mathrm{~mL}$ of supernatant was taken in a $50 \mathrm{~mL}$ flask to which $10 \mathrm{~mL}$ of chloromolybdic acid was added and mixed thoroughly. The volume was made up to three-fourths with distilled water and $0.25 \mathrm{~mL}$ of chlorostannous acid was added. Immediately the volume was made up to $50 \mathrm{~mL}$ with distilled water. After $15 \mathrm{~min}$ the blue colour developed was read on a spectrophotometer at $610 \mathrm{~nm}$ using reagent blank. A standard curve was prepared using different concentrations of standard potassium dihydrogen phosphate solution. The amount of inorganic phosphorus released was calculated from the standard graph.

2.3.2. Indole Acetic Acid Production. All the endophytic bacterial isolates were screened for the production of IAA according to the modified method as described by Noori and Saud [12]. The test bacterial culture was inoculated in the two sets of nutrient broth tubes, one tube supplemented with $5 \mu \mathrm{g} \mathrm{mL}^{-1}$ of L-tryptophan and incubated at $28 \pm$ $2^{\circ} \mathrm{C}$ for 5 days. Cultures were centrifuged at $10.000 \mathrm{rpm}$ for $10 \mathrm{~min}$ and $1 \mathrm{~mL}$ of the supernatant was mixed with a drop of orthophosphoric acid and $2 \mathrm{~mL}$ of Salkowski's reagent $\left(50 \mathrm{~mL}, 35 \%\right.$ perchloric acid; $\left.1 \mathrm{~mL} 0.5 \mathrm{M} \mathrm{FeCl}_{3}\right)$ and incubated at room temperature for $30 \mathrm{~min}$ in the dark. The appearance of red to pink colour indicates IAA production. 
Spectrophotometric absorbance at $535 \mathrm{~nm}$ was quantified as $\mu \mathrm{g} \mathrm{mL}^{-1}$ by comparing with known standard of IAA. Nutrient broth without bacterial culture serves as control.

2.3.3. Siderophore Production. Siderophores are iron chelating compounds produced by many bacteria. Siderophore production was determined by the method of Schwyn and Neilands [13]. For this, pure culture of endophytic bacteria was spotted onto plates containing CAS (Chrome Azurol S) agar and the plates were incubated at $30^{\circ} \mathrm{C}$ for $2-6$ days. The plates with yellow halo indicate production of siderophore.

2.3.4. Cyanogenesis (HCN Production). HCN production by the endophytic bacterial strains was detected by the method of Lorck [14]. The endophytic bacterial strains were grown in nutrient agar supplemented with glycine $\left(4.4 \mathrm{~g} \mathrm{~L}^{-1}\right)$. A disc of the sterilized Whatman filter paper was immersed in $1 \%$ picric acid in $10 \% \mathrm{Na}_{2} \mathrm{CO}_{3}$ for $1 \mathrm{~min}$ and was placed underneath the Petri plate lids under aseptic condition. The plates were sealed with Parafilm and were incubated at $28 \pm$ $1^{\circ} \mathrm{C}$ for $24-72 \mathrm{~h}$. Change in colour from yellow to reddish brown of filter paper indicated production of HCN. In case of a negative test, the deep yellow colour of the filter paper remained unchanged after growth of bacteria.

2.3.5. Ability to Produce Exopolysaccharide by Endophytic Bacteria. Exopolysaccharide production ability of endophytic bacterial isolates was tested by the plate assay containing nutrient media with high (5\%) sucrose concentration $\left(\mathrm{g} \mathrm{L}^{-1}\right.$; beef extract 3 , sucrose 50 , peptone $5, \mathrm{NaCl} 5$, agar 15 , and $\mathrm{pH} 7$ ). The isolates were streaked on the plates and incubated at $30^{\circ} \mathrm{C}$ for $4-7$ days. The plates were examined for thick, viscous mass over the streak and considered as positive for polysaccharides production [15].

2.3.6. Growth on Nitrogen-Free Media by Endophytic Bacteria. Endophytic bacterial isolates were tested for their ability to grow in nitrogen-free media as described by Anu Rajan [15]. Nitrogen-free mannitol agar medium ( $\mathrm{gL}^{-1}$; mannitol 10, $\mathrm{CaCO}_{3} 5, \mathrm{~K}_{2} \mathrm{HPO}_{4}$ 0.5, $\mathrm{MgSO}_{4} \cdot 7 \mathrm{H}_{2} \mathrm{O} 0.2, \mathrm{NaCl} 0.2$, ferric chloride-trace amount, $\mathrm{MnSO}_{4} \cdot 4 \mathrm{H}_{2} \mathrm{O}$-trace amount, agar 15 , and $\mathrm{pH}$ 7.0) and Jensen's medium ( $\mathrm{g} \mathrm{L}^{-1}$; sucrose 20, $\mathrm{K}_{2} \mathrm{HPO}_{4}$ $1, \mathrm{MgSO}_{4} 0.5, \mathrm{NaCl} 0.5, \mathrm{Na}_{2} \mathrm{MoO}_{4}$ 0.001, $\mathrm{FeSO}_{4} 0.01, \mathrm{CaCO}_{3}$ 2 , agar 15, pH 7.0) were used because carbon sources of these media are different. Precaution was taken to avoid any nitrogen source in the media and glassware. Streaked endophytic bacterial isolates on the above mentioned media were incubated at $30^{\circ} \mathrm{C}$ for about 1 week. Growth of endophytic bacterial isolates with glistening colonies in the above nitrogen-free media was identified as positive for nitrogen fixation.

\subsubsection{Abiotic Stress Tolerance Evaluation of Bacterial Endophytes}

Salt ( $\mathrm{NaCl}), \mathrm{pH}$, and Heavy Metal $\left(\mathrm{Al}^{+3}\right.$ and $\left.\mathrm{Mn}^{+2}\right)$ Tolerance. Nutrient agar (NA) medium containing 2-10\% $\mathrm{NaCl}$ was used for salt $(\mathrm{NaCl})$ tolerance ability of endophytic bacterial strains [1]. After increasing the salt concentration, the bacterial cultures were streaked on the Petri plates and incubated at $28 \pm 1^{\circ} \mathrm{C}$ for $48 \mathrm{~h}$ to see their growth. The endophytic bacterial isolates were screened for tolerance to acidic $\mathrm{pH}$ on YEM plates set at 3.0, 4.0,5.0,6.0, and $6.9 \mathrm{pH}$ values, using the (20 mM) MES (SIGMA) buffers. The medium was buffered with $\mathrm{HCl}$ to set the desired $\mathrm{pH}$ values. The endophytic bacterial isolates were screened for tolerance to heavy metals, namely, $\mathrm{Al}^{+3}$ and $\mathrm{Mn}^{+2}$, according to the modified method of Konate et al. [16]. The tolerance of isolates to $\mathrm{Al}^{+3}$ and $\mathrm{Mn}^{+2}$ was determined on solid YEM medium. The stock solutions of $\mathrm{Al}^{+3}$ and $\mathrm{Mn}^{+2}$ metals were filter-sterilized and added to sterile agar as the following concentrations: $\mathrm{AlCl}_{3}$, 400-600 $\mu \mathrm{g} \mathrm{mL}^{-1}$, and $\mathrm{MnCl}_{2}, 500-600 \mu \mathrm{g} \mathrm{mL}^{-1}$.

In Vitro Antagonistic Activity. The antagonistic activity of all endophytic bacterial isolates was studied under in vitro condition against fungal pathogens Sclerotium rolfsii and Sclerotinia sclerotiorum by the dual culture plate technique on potato dextrose agar (PDA) [17]. A fungal pathogen mycelial disc of $5 \mathrm{~mm}$ was placed in the middle of Petri plate and incubated at $28^{\circ} \mathrm{C}$ for 24 hours. After that a loophole of endophytic bacterial culture was then streaked to either side of the pathogen disc at equidistance on the same dish. After 1 week the zone of inhibition as the distance between the fungal pathogen and endophytic bacterial culture was recorded. Based on the efficacy of antagonistic activity of endophytic bacteria, percent growth inhibition (PGI) and growth inhibition category (GIC) were analyzed and bacterial endophytes were categorized accordingly [18]:

$$
\begin{aligned}
& \text { Percent Growth Inhibition (PGI) \% } \\
& =\frac{K R-R 1}{K R} \times 100,
\end{aligned}
$$

where $K R$ is the distance (in $\mathrm{mm}$ ) from the point of inoculation to the colony margin of fungal pathogen on the control dishes and $R 1$ is the distance (in $\mathrm{mm}$ ) from the point of inoculation to the colony margin of fungal growth on the endophytic bacterial culture inoculated dishes.

Based on the efficiency of PGI endophytic bacterial isolates were categorized into five growth inhibition categories, with ranges from 0 to 4: (0) no growth inhibition, (1) up to $25 \%$ growth inhibition, (2) up to $50 \%$ growth inhibition, (3) up to $75 \%$ growth inhibition, and (4) up to $100 \%$ growth inhibition.

2.4. Data Analysis. All the experiments were performed in triplicate. Data were analyzed by one-way analysis of variance (ANOVA) and the mean separations were performed by Tukey HSD posttest with SPSS version 16 (IBM Corporation, Armonk, NY, USA). Differences at $P<0.05$ were considered significant.

\section{Results and Discussion}

A total of seven endophytic bacterial isolates were selected for the further studies based on the distinct colony characteristics isolated from the Mussaenda roxburghii's stem, leaves, and 
TABLE 1: Results of morphological and biochemical and carbohydrate utilization and enzymatic activity of endophytic bacterial isolates.

\begin{tabular}{|c|c|c|c|c|c|c|c|}
\hline \multirow{2}{*}{ Characters tested } & \multicolumn{7}{|c|}{ Endophytic bacterial isolates } \\
\hline & PAK1 & PAK2 & PAK3 & PAK6 & PAK7 & PAK8 & PAK9 \\
\hline \multicolumn{8}{|l|}{ Morphological } \\
\hline Colonial surface & Smooth & Smooth & Smooth & Smooth & Concentric & Smooth & Smooth \\
\hline Colony edge & Pinpointed & Fluidic smooth & Pinpointed & Pinpointed & Irregular & Pinpointed & Irregular \\
\hline Colony elevation & Flat & Flat & Convex & Flat & Raised & Raised & Raised \\
\hline Margin & Serrated & Serrated & Entire & Lobate & Lobate & Undulated & Undulated \\
\hline Pigmentation & White & White & White & White & Orange & White & Yellowish \\
\hline \multicolumn{8}{|l|}{ Biochemical } \\
\hline Gram stain & - & - & - & - & - & - & - \\
\hline Motility & + & + & + & $-1+$ & $-1+$ & + & + \\
\hline Nitrate reduction & + & + & + & - & + & + & - \\
\hline $\mathrm{H} 2 \mathrm{~S}$ & - & - & - & + & - & + & - \\
\hline Indole & - & - & - & - & - & - & - \\
\hline MR test & + & + & + & + & + & + & + \\
\hline VP test & - & - & - & - & - & - & - \\
\hline Citrate utilization & + & - & - & - & - & - & - \\
\hline Oxidase & + & + & - & - & + & + & - \\
\hline Catalase & + & + & + & + & + & + & + \\
\hline \multicolumn{8}{|l|}{ Carbohydrate utilization } \\
\hline Glucose & - & + & + & + & - & + & + \\
\hline Sucrose & - & + & + & + & - & - & + \\
\hline Lactose & - & - & + & + & - & - & - \\
\hline Mannitol & - & - & + & - & - & - & - \\
\hline Mannose & - & + & + & + & + & - & - \\
\hline \multicolumn{8}{|l|}{ Enzymatic activity } \\
\hline Amylase & - & - & - & - & + & + & - \\
\hline Gelatinase & - & - & - & - & + & - & - \\
\hline Pectinase & - & - & - & + & - & - & + \\
\hline Urease & - & - & + & - & - & - & - \\
\hline Tentative identification & $\begin{array}{l}\text { Pseudomonas } \\
\text { sp. }\end{array}$ & Pseudomonas sp. & Klebsiella sp. & $\begin{array}{c}\text { Acinetobacter } \\
\text { sp. }\end{array}$ & $\begin{array}{l}\text { Pseudomonas } \\
\text { sp. }\end{array}$ & $\begin{array}{l}\text { Pseudomonas } \\
\text { sp. }\end{array}$ & $\begin{array}{c}\text { Acinetobacter } \\
\text { sp. }\end{array}$ \\
\hline
\end{tabular}

+: positive reaction; -: negative reaction.

root. The surface sterilization is quite satisfactory as no growth was observed on the control plate and, hence, the isolates are considered as endophytic bacteria of Mussaenda roxburghii.

3.1. Characterization. Morphological and biochemical characterization of all isolates were given in Table 1. All the seven endophytic bacterial strains are Gram-negative rods and showed negative results for endospore staining. Out of seven isolates, six strains are motile while one is able to produce hydrogen sulfide. All the endophytic bacterial strains were positive towards the nitrate reduction test and MR test and negative towards indole formation, VP test, and citrate utilization test (Table 1). Fermentative degradation of various carbohydrates, namely, glucose, sucrose, lactose, mannitol, and mannose, by endophytic bacterial isolates was carried out in a fermentation tube that contains a Durham tube for the detection of gas production as an end product of metabolism and listed in Table 1 . The enzymatic activity, namely, amylase, lipase, pectinases, and urease, of the endophytic bacterial isolates was examined and listed in Table 1. In the case of pectinase activity no clear zone was observed by any endophytic bacterial isolates, but the clear zone beneath the bacterial culture was considered as positive. All the isolates were tentatively characterized, grouped, and documented (Table 1).

\subsection{Plant Beneficial Traits}

3.2.1. Phosphate Solubilization Activity of Endophytic Bacteria. Isolates PAK2, PAK3, PAK6, and PAK8 do have ability to solubilize inorganic phosphate supplemented with NBRIBPB agar medium and the isolate PAK6 has the highest phosphate solubilization index of $314.2 \pm 10.0$ (Figure 1). Isolates 


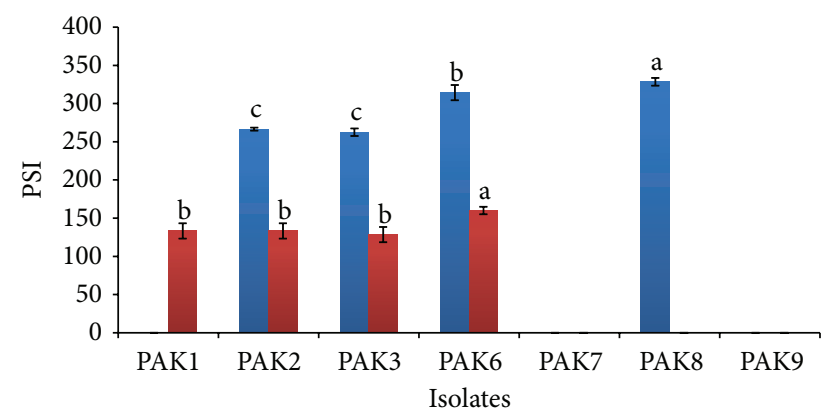

- Phosphate solubilization index (NBRI-BPB medium)

- Phosphate solubilization index (Pikovskaya's agar)

Figure 1: Phosphate solubilization index by endophytic bacterial isolates of Mussaenda roxburghii. Values are mean values + SD from three replications and lower-case letters above the end of bar show the significant difference between experiments $(P<0.05)$.

PAK1, PAK2, PAK3, and PAK6 do have ability to solubilize inorganic phosphate supplemented with Pikovskaya's agar medium and the isolate PAK6 was found to have the highest phosphate solubilization index of $160.00 \pm 5.0$ (Figure 1). In molybdenum blue method all the isolates were reported to solubilize inorganic phosphate more than $3.7 \mathrm{ppm}$ with the isolate PAK6 found to solubilize highest amount of $5.24 \pm$ 0.125 inorganic phosphate (Figure 2). Phosphate solubilizing microorganisms play an important role in supplementing phosphorus to the plants and increase the crop yield [19], through lowering the $\mathrm{pH}$ by organic acid production [20].

3.2.2. Indole Acetic Acid (IAA) Production. All the endophytic bacterial isolates exhibited a significant amount of IAA. The data compared the presence and absence of tryptophan. Four isolates PAK1, PAK2, PAK3, and PAK8 were able to produce high IAA in the presence of tryptophan and hence indicate the utilization of tryptophan during IAA synthesis while isolates PAK6, PAK7, and PAK9 were found to produce low amount of IAA even in the presence of tryptophan. The endophytic bacterial isolates PAK1 and PAK3 were identified as potential isolates to produce IAA, respectively. In which PAK1 $\left(16.86 \pm 0.20\right.$ in presence of $5 \mu \mathrm{g} \mathrm{mL}^{-1}$ of Ltryptophan and $15.26 \pm 0.20$ in absence of L-tryptophan) were identified as highest producers of IAA (Figure 3). Different bacterial groups were reported to produce the IAA (indole-3acetic acid), the most important auxin which regulates plant development such as cell expansion, division, differentiation, gene regulation, and other tropic responses [21]. Endophyte from the ginger root was identified and its ability to produce IAA was studied under various conditions [22].

\subsubsection{Siderophore Production Activities of Endophytic Bacte-} ria. Term siderophores belongs to a molecule which chelates the iron. They are generally less than about 1000 molecular weight and are produced by many microorganisms [23]. Their biosynthesis is influenced by the presence of iron; for example, their synthesis is repressed if the presence of iron is abundant in the environment [24]. Production of

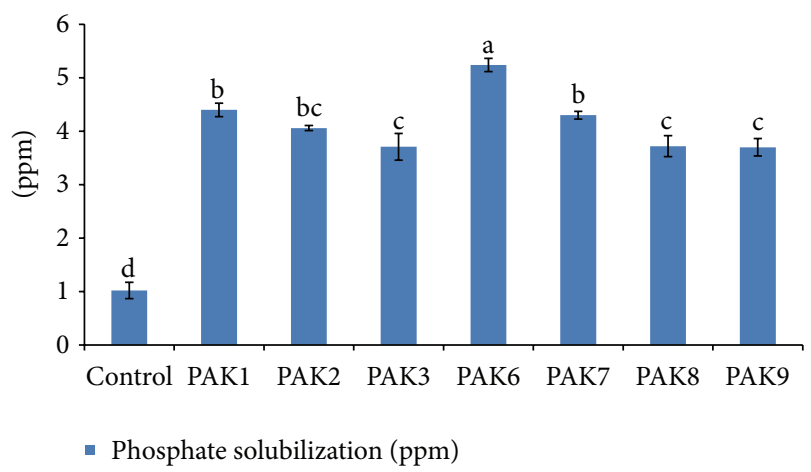

FIGURE 2: Estimation of inorganic phosphate solubilization (ppm) by endophytic bacterial isolates of Mussaenda roxburghii. Values are mean values + SD from three replications and lower-case letters above the end of bar show the significant difference between experiments $(P<0.05)$.

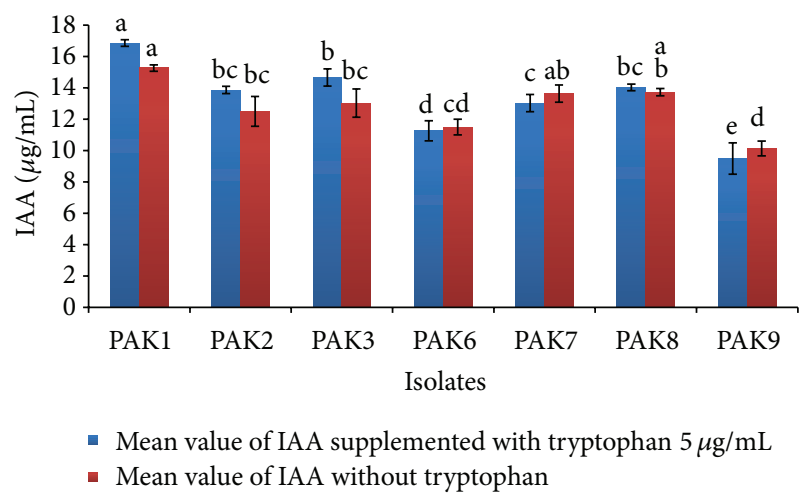

FIGURE 3: IAA production by the endophytic bacterial isolates of Mussaenda roxburghii. Values are mean + SD from three replications and lower-case letters above the end of bar show the significant difference between experiments $(P<0.05)$.

siderophore is very important because of the leading role of iron in the nitrogen fixation and assimilation processes. In the siderophore production experiment by the endophytic bacteria, isolates PAK1 and PAK9 were able to produce siderophore on CAS agar media (Table 2). Under iron limiting conditions, microbes and plant secrete siderophore form complex with iron and help in transport of iron inside the cell. As a result of siderophore production by endophytic bacteria, iron shortage of plant is neutralized which helps in the enhancement of the plant growth and yield [13]. Siderophore producing microbes can take away the limited iron and thus reduce its availability for growth of phytopathogens. They facilitate the plant growth promotion indirectly [22]. Siderophoresecreting bacteria inside the plant tissues help in the transport of $\mathrm{Fe}^{3+}$ inside the plant cell and contribute to the plant growth and productivity via synthesis of ATP, DNA precursor, and the heme $[13,23]$.

3.2.4. Cyanogenesis (HCN Production). Endophytic bacterial isolates PAK2 and PAK9 were able to produce HCN (Table 2). Cyanogenesis from glycine results in the production of $\mathrm{HCN}$, 
TABLE 2: Results of siderophore, $\mathrm{HCN}$ production, salt $(\mathrm{NaCl}), \mathrm{pH}$, heavy metal $\left(\mathrm{Al}^{+3}\right.$ and $\left.\mathrm{Mn}^{+2}\right)$ tolerance, growth on $\mathrm{N}$-free media, and polysaccharide production by endophytic bacterial isolates.

\begin{tabular}{|c|c|c|c|c|c|c|c|}
\hline \multirow{2}{*}{ Characters tested } & \multicolumn{7}{|c|}{ Endophytic bacterial isolates } \\
\hline & PAK1 & PAK2 & PAK3 & PAK6 & PAK7 & PAK8 & PAK9 \\
\hline Siderophore production & ++ & - & - & - & - & - & ++ \\
\hline $\mathrm{HCN}$ production & - & ++ & - & - & - & - & ++ \\
\hline \multicolumn{8}{|l|}{ Salt tolerance $(\mathrm{NaCl})$} \\
\hline $2 \%$ & +++ & +++ & +++ & +++ & +++ & +++ & + \\
\hline $4 \%$ & +++ & +++ & +++ & ++ & +++ & +++ & + \\
\hline $6 \%$ & +++ & +++ & +++ & +++ & +++ & +++ & + \\
\hline $8 \%$ & +++ & +++ & +++ & +++ & +++ & +++ & + \\
\hline $10 \%$ & +++ & +++ & ++ & ++ & ++ & ++ & + \\
\hline \multicolumn{8}{|l|}{$\mathrm{pH}$ tolerance } \\
\hline 6.9 & + & + & +++ & +++ & +++ & ++ & + \\
\hline 6.0 & - & + & ++ & + & +++ & ++ & - \\
\hline 5.0 & - & - & + & + & ++ & + & - \\
\hline 4.0 & - & - & - & - & - & - & - \\
\hline 3.0 & - & - & - & - & - & - & - \\
\hline \multicolumn{8}{|l|}{ Heavy metal tolerance } \\
\hline $\mathrm{Al}^{+3}$ tolerance $(400 \mu \mathrm{g} / \mathrm{mL})$ & - & + & + & + & + & + & + \\
\hline $\mathrm{Al}^{+3}$ tolerance $(500 \mu \mathrm{g} / \mathrm{mL})$ & - & + & + & + & + & + & - \\
\hline $\mathrm{Al}^{+3}$ tolerance $(600 \mu \mathrm{g} / \mathrm{mL})$ & - & + & - & - & + & + & - \\
\hline $\mathrm{Mn}^{+2}$ tolerance $(500 \mu \mathrm{g} / \mathrm{mL})$ & + & + & + & + & + & + & + \\
\hline $\mathrm{Mn}^{+2}$ tolerance $(600 \mu \mathrm{g} / \mathrm{mL})$ & - & + & + & + & + & + & + \\
\hline \multicolumn{8}{|l|}{ Growth on N-free media } \\
\hline Jensen’s medium & - & + & - & - & + & + & - \\
\hline N-free mannitol agar & - & - & - & - & + & + & + \\
\hline \multicolumn{8}{|l|}{ Polysaccharide production } \\
\hline 24 hours & + & ++ & + & ++ & + & + & ++ \\
\hline 48 hours & ++ & ++ & ++ & ++ & ++ & ++ & ++ \\
\hline
\end{tabular}

-: no growth; +: slight growth; ++: moderate growth; +++: high growth.

which is volatile in nature. $\mathrm{HCN}$ acts as an inducer of resistance and constitutes a mechanism of defence against pathogen in plants [25].

\subsubsection{Polysaccharide Production and Growth on N-Free} Media. Naturally bacterial surfaces are covered by a glycocalyx which is primarily made up of exopolysaccharide (EPS). Exopolysaccharide has been useful to act as adhesion for the interaction of microbes with the host surfaces [26]. The ability of endophytic bacteria to produce polysaccharide was recorded at the intervals of 24 hours and 48 hours of incubation period in plates at $30^{\circ} \mathrm{C}$ and listed in Table 2 . The plates were visually observed for the production of viscous gelatinous mass of polysaccharide. All the isolates were able to produce a moderate level of polysaccharide production after $48 \mathrm{~h}$ of incubation.

The ability of the endophytic bacterial isolates to grow on nitrogen-free media, namely, Jensen's and N-free mannitol agar medium, was examined and listed in Table 2. Of the seven isolates examined, three isolates PAK2, PAK7, and PAK8 were able to grow on Jensen's nitrogen-free medium while the three isolates PAK7, PAK8, and PAK9 were able to grow on Waksman 77 medium (Table 2). Cajanus cajan (L.) native diazotrophs Pseudomonas sp. JJS2 of Western Indian Himalayas showed good growth on N2-free media at room temperature; their nif $\mathrm{H}$ fragment amplification confirms their diazotrophic nature [27]. An inoculation of the diazotrophs significantly improves the crop productivity and biomass in contrast to uninoculated control crop [28].

\subsubsection{Abiotic Stress Tolerance}

Salt ( $\mathrm{NaCl}$, $\mathrm{pH}$, and Heavy Metal $\left(\mathrm{Al}^{+3}\right.$ and $\left.\mathrm{Mn}^{+2}\right)$ Tolerance. Endophytic bacterial strains showed good growth at the level of $2.0-10 \% \mathrm{NaCl}$ (Table 2). Salinity affects many aspects of plant metabolism and the accumulation of various organic solutes that contribute to turgor maintenance. According to an estimate more than $20 \%$ of agricultural soil faces increase in salinity problems [29] and nearly 50\% of the agriculturally important land will be affected by salinity stress by the year 2050 [30]. Rising of salt concentrations in soil and irrigation water creates a key threat to agricultural scenario, which could be managed by bacterial endophytes by osmotic adjustments, stomatal regulation, root morphology 
modification, and increase in uptake of minerals and by reducing the toxic effects of $\mathrm{Na}^{+}$and $\mathrm{Cl}^{-}[1]$.

All the isolates were tested for variable $\mathrm{pH}$. All the isolates were grown at $\mathrm{pH}$ 6.9. Five isolates were able to grow well at $\mathrm{pH} 6.0$ and four isolates were able to grow at $\mathrm{pH} 5.0$. Isolate $\mathrm{PAK} 7$ was identified to grow well at $\mathrm{pH} 5.0$ among all isolates (Table 2). Endophytic bacterial isolates PAK2, PAK7, and PAK8 were able to tolerate $600 \mu \mathrm{g} \mathrm{mL}^{-1}$ of $\mathrm{Al}^{+3}$ and all the isolates except PAK1 showed a tolerance to $600 \mu \mathrm{g} \mathrm{mL}^{-1}$ of $\mathrm{Mn}^{+2}$ tested (Table 2). Aluminium toxicity is one of the main abiotic stress factors that causes about $25-80 \%$ yield losses in various crop plants grown on soils with excessive Aluminium contents [31]. Indian land comprises 49 million ha soil affected by acidity in which 24 million ha has a $\mathrm{pH}$ below 5.5 [32] and 95\% soil area of northeastern region of India is affected by acidity [33]. Acidic soil engaged with poor crop productivity and low soil fertility due to the combined effect of Aluminium and Manganese toxicities coupled with nutrient deficiencies (P, $\mathrm{Ca}, \mathrm{Mg}$, and $\mathrm{K}$ ).

In Vitro Antagonistic Activity Evaluation of Endophytic Bacteria. The efficacy of antagonistic activity of endophytic bacterial isolates against soil borne plant pathogenic fungi Sclerotium rolfsii and Sclerotinia sclerotiorum by dual plate in vitro assay varied from poor to reasonable and the results showed that the bacterial endophytic isolates in dual culture evaluation inhibit the mycelia growth of fungal pathogens. Isolate PAK9 $(52.5 \pm 10.0)$ reasonably inhibited the mycelia growth of Sclerotium rolfsii and belonged to the growth inhibition categories (GIC) of 3 while five isolates, namely, PAK6 (44.17 \pm 2.5$)$, PAK7 (42.5 \pm 2.5$)$, PAK8 (42.5 \pm 2.5), PAK2 (37.5 \pm 5.0$)$, and PAK1 (30.0 \pm 12.5$)$ (Figure 4), showed a good scale of antagonistic activity with GIC of 2 . Similarly, of the seven isolates evaluated against Sclerotinia sclerotiorum (Figure 4) two isolates, namely, PAK6 (62.5 \pm 5.0$)$ and PAK9 $(62.5 \pm 10.0)$, reasonably inhibited the mycelia growth of Sclerotinia sclerotiorum and belonged to the growth inhibition categories (GIC) of 3. Two isolates, namely, PAK7 $(47.5 \pm 2.5)$ and PAK8 $(47.5 \pm 2.5)$, showed a good extent of antagonistic activity with GIC of 2 (Figure 4).

Endophytic bacterial isolates PAK6 and PAK9 showed very good antagonistic activity against Sclerotinia sclerotiorum and Sclerotium rolfsii, which remained constant over time. Hence, they must be used as a biocontrol agent to inhibit pathogen growth and development in crop plants by direct antagonistic mechanisms or induced resistance in the host plant by producing several metabolites that have an important role in inducing ISR against many plant diseases or produce lytic enzymes such as chitinases and glucanases which act on cell walls of organisms. Biological control may have been applied as an alternative to replace chemicals to control various plant diseases.

\section{Conclusion}

In the present study, our effort is to explore the ethnomedicinal plant Akshap (Mussaenda roxburghii) associated untapped endophytic bacterial isolate from the Eastern

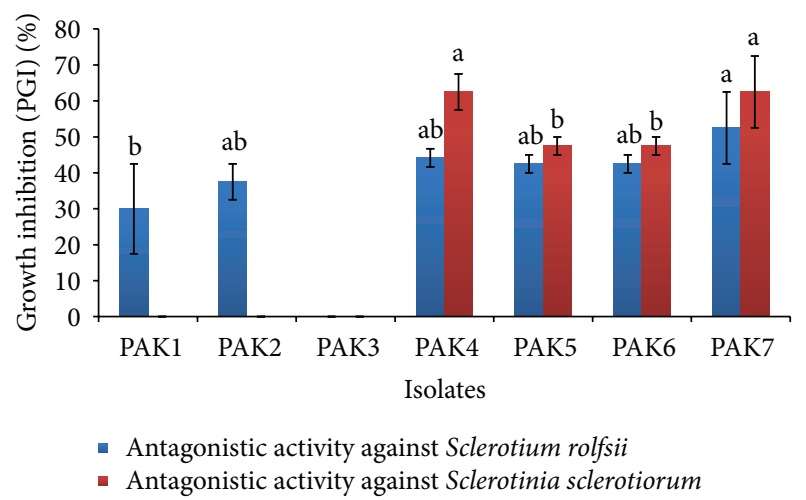

FIGURE 4: Antagonistic activities by endophytic bacterial isolates of Mussaenda roxburghii. Values are mean values + SD from three replications and lower-case letters above the end of bar show the significant difference between experiments $(P<0.05)$.

Himalayan province of India. The results from the present study point out that Mussaenda roxburghii were associated with potential endophytic bacteria, which can be utilized in future as an option for plant growth promoting agents and for controlling plant diseases. Mussaenda roxburghii associated endophytic isolate PAK1 was found to solubilize inorganic phosphate efficiently and significantly produces IAA and siderophore. Isolate PAK9 was identified to produce siderophore and $\mathrm{HCN}$ and was effective against the soil borne fungal plant pathogens Sclerotium rolfsii and Sclerotinia sclerotiorum. With all the above concern contents, these isolates may be developed as new inocula to utilize in agriculture sector and in industry.

\section{Conflict of Interests}

The authors did not declare any conflict of interests.

\section{Acknowledgments}

Authors are grateful to the Vice-Chancellor, Dibrugarh University, for providing necessary facilities for research work and financial support from the Department of Biotechnology (DBT), Govt. of India, for the Project Establishment of Institutional Biotechnology Hub is acknowledged.

\section{References}

[1] P. K. Pandey, S. K. Yadav, A. Singh, B. K. Sarma, A. Mishra, and H. B. Singh, "Cross-species alleviation of biotic and abiotic stresses by the endophyte Pseudomonas aeruginosa PW09," Journal of Phytopathology, vol. 160, no. 10, pp. 532-539, 2012.

[2] R. P. Ryan, K. Germaine, A. Franks, D. J. Ryan, and D. N. Dowling, "Bacterial endophytes: recent developments and applications," FEMS Microbiology Letters, vol. 278, no. 1, pp. 1-9, 2008.

[3] R. K. Singh, R. C. Srivastava, Adi Community, and Monpa Community, "Bioculturally important plant diversity of Arunachal Pradesh; learning from Adi and Monpa communities 
about 'future crops of India,' Indian Journal of Traditional Knowledge, vol. 9, no. 4, pp. 754-759, 2010.

[4] C. De Utpal, R. Ghosh, S. Chowdhury, and B. Dinda, "New iridoid from aerial parts of Mussaenda roxburghii," Natural Product Communications, vol. 7, no. 1, pp. 1-2, 2012.

[5] J. Saha, P. K. Sarkar, and S. Chattopadhyay, "A survey of ethnomedicinal plants of Darjeeling hills for their antimicrobial and antioxidant activities," Indian Journal of Natural Products and Resources, vol. 2, no. 4, pp. 479-492, 2011.

[6] S. A. Patil and V. G. Joshi, "Evaluation of antibacrerial and wound healing activity of leaves of Mussaenda frondosa linn," International Journal of Research in Pharmaceutical and Biomedical Sciences, vol. 2, no. 1, pp. 147-154, 2011.

[7] H. B. Das, K. Majumdar, B. K. Datta, and D. Ray, "Ethnobotanical uses of some plants by Tripuri and Reang tribes of Tripura," Natural Product Radiance, vol. 8, no. 2, pp. 172-180, 2009.

[8] F. Islam, M. R. Kuddus, F. Latif, and M. K. Hossain, "Preliminary antimicrobial activity and cytotoxicity of leaf extracts of Mussaenda roxburghii Hook. f." Boletín Latinoamericano y del Caribe de Plantas Medicinales y Aromáticas, vol. 12, no. 6, pp. 612-617, 2013.

[9] S. Mehta and C. S. Nautiyal, "An efficient method for qualitative screening of phosphate solubilizing bacteria," Current Microbiology, vol. 43, no. 1, pp. 51-56, 2001.

[10] R. I. Pikovskaya, "Mobilization of phosphates in soil in connection with the vital activities of some microbial species," Mikrobiologia, vol. 17, pp. 362-370, 1948.

[11] J. Murphy and J. P. Riley, "A modified single solution method for the determination of phosphate in natural waters," Analytica Chimica Acta, vol. 27, pp. 31-36, 1962.

[12] M. S. S. Noori and H. M. Saud, "Potential plant growthpromoting activity of Pseudomonas sp isolated from paddy soil in Malaysia as biocontrol agent," Journal of Plant Pathology \& Microbiology, vol. 3, article 120, 2012.

[13] B. Schwyn and J. B. Neilands, "Universal chemical assay for the detection and determination of siderophores," Analytical Biochemistry, vol. 160, no. 1, pp. 47-56, 1987.

[14] H. Lorck, "Production of hydrocyanic acid by bacteria," Physiologia Plantarum, vol. 1, no. 2, pp. 142-146, 1948.

[15] S. Anu Rajan, Microbial endophytes of crop plants and their role in plant growth promotion [Ph.D. thesis], University of Agricultural Sciences, Bangalore, India, 2012.

[16] I. Konate, A. Koulibaly, M. Koffi, A. Sorouri, E. B. Berraho, and A. Filali-Maltouf, "Phenotypic variations of endophytic bacteria associated with carob tree (Ceratonia Siliqua L.)," American Journal of Life Sciences, vol. 2, no. 5, pp. 325-332, 2014.

[17] C. Dennis and J. Webster, "Antagonistic properties of species groups of Trichoderma production of non-volatile antibiotics," Transactions of the British Mycological Society, vol. 57, no. 1, pp. 25-39, 1971.

[18] J. Dalal and N. Kulkarni, "Antagonistic and plant growth promoting potentials of indigenous endophytic bacteria of soybean (Glycine max (L) Merril)," Current Research in Microbiology and Biotechnology, vol. 1, no. 2, pp. 62-69, 2013.

[19] M. Toro, R. Azcón, and J.-M. Barea, "Improvement of arbuscular mycorrhiza development by inoculation of soil with phosphate-solubilizing rhizobacteria to improve rock phosphate bioavailability $\left({ }^{32} \mathrm{P}\right)$ and nutrient cycling," Applied and Environmental Microbiology, vol. 63, no. 11, pp. 4408-4412, 1997.

[20] K. S. Yadav and K. R. Dadarwal, "Phosphate solubilization and mobilization through soil microorganisms," in Biotechnological
Approaches in Soil Microorganisms for Sustainable Crop Production, K. R. Dadarwal, Ed., pp. 293-308, Scientific Publishers, Jodhpur, India, 1997.

[21] R. Nath, G. D. Sharma, and M. Barooah, "Screening of endophytic bacterial isolates of tea (Camellia sinensis L.) roots for their multiple plant growth promoting activities," International Journal of Agriculture, Environment and Biotechnology, vol. 6, no. 3, pp. 371-376, 2013.

[22] B. Jasim, A. A. Joseph, C. J. John, J. Mathew, and E. K. Radhakrishnan, "Isolation and characterization of plant growth promoting endophytic bacteria from the rhizome of Zingiber officinale," 3 Biotech, vol. 4, no. 2, pp. 197-204, 2014.

[23] J. B. Neilands, "Siderophores: Structure and function of microbial iron transport compounds," The Journal of Biological Chemistry, vol. 270, no. 45, pp. 26723-26726, 1995.

[24] J. B. Neilands, "Microbial envelope proteins related to iron," Annual Review of Microbiology, vol. 36, pp. 285-309, 1982.

[25] F. Alemu and T. Alemu, "Pseudomonas fluorescens Isolates used as a plant growth promoter of Faba Bean (Vicia faba) in vitro as well as in vivo study in Ethiopia," American Journal of Life Sciences, vol. 3, no. 2, pp. 100-108, 2015.

[26] T. Takahashi and N. Doke, "A role of extracellular polysaccharides of Xanthomonas campestris pv. citri in bacterial adhesion to citrus leaf tissues in preinfectious stage," Annals of the Phytopathological Society of Japan, vol. 50, no. 5, pp. 565-573, 1984.

[27] A. Shukla, N. Dhauni, D. C. Suyal, S. Kumar, and R. Goel, "Comparative plant growth promoting potential of psychrotolerant diazotrophs, Pseudomonas sp. JJS2 and Enterobacter sp. AAB8 against native Cajanus cajan (L.) and Eleusine coracana (L.)," African Journal of Microbiology Research, vol. 9, no. 20, pp. 13711375, 2015.

[28] D. C. Suyal, A. Shukla, and R. Goel, "Growth promotory potential of the cold adapted diazotroph Pseudomonas migulae S10724 against native green gram (Vigna radiata (L.) Wilczek)," 3 Biotech, vol. 4, no. 6, pp. 665-668, 2014.

[29] J. K. Zhu, "Over expression of a delta-pyrroline-5-carboxylate synthetase gene and analysis of tolerance to water and salt stress in transgenic rice," Trends in Plant Science, vol. 6, pp. 66-72, 2000.

[30] R. Munns and M. Tester, "Mechanisms of salinity tolerance," Annual Review of Plant Biology, vol. 59, pp. 651-681, 2008.

[31] D. Singh, N. P. Singh, S. K. Chauhan, and P. Singh, "Developing aluminium-tolerant crop plants using biotechnological tools," Current Science, vol. 100, no. 12, pp. 1807-1814, 2011.

[32] S. C. Mandal, "Introduction and historical overview," in Acidic Soils of India, I. C. Mahapatra, S. C. Mandal, C. Misra, G. N. Mitra, and N. Panda, Eds., pp. 3-24, ICAR, New Delhi, India, 1997.

[33] U. C. Sharma and R. P. Singh, "Acid soils of India: their distribution, management and future strategies for higher productivity," Fertilizer News, vol. 47, pp. 45-52, 2002. 

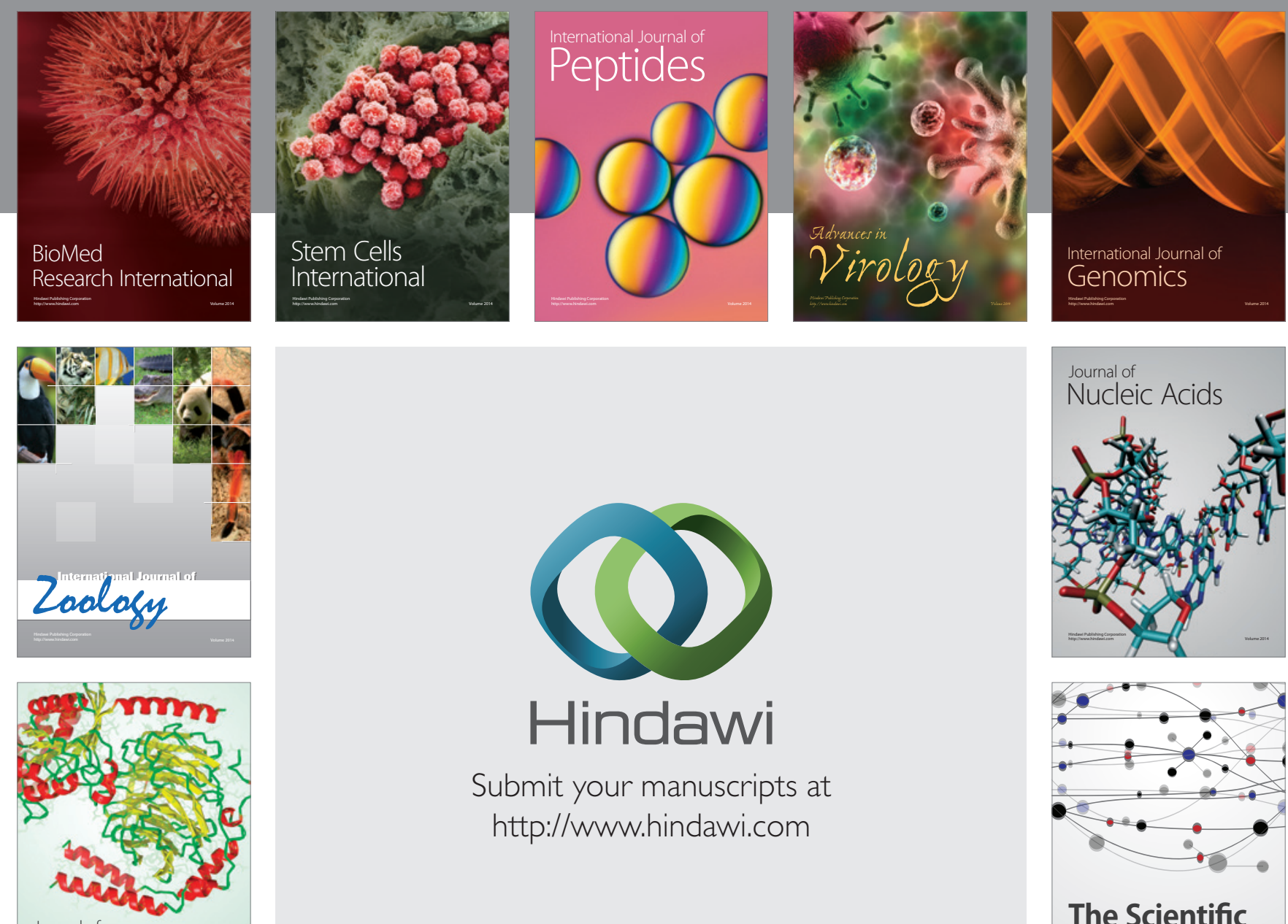

Submit your manuscripts at

http://www.hindawi.com

Journal of
Signal Transduction
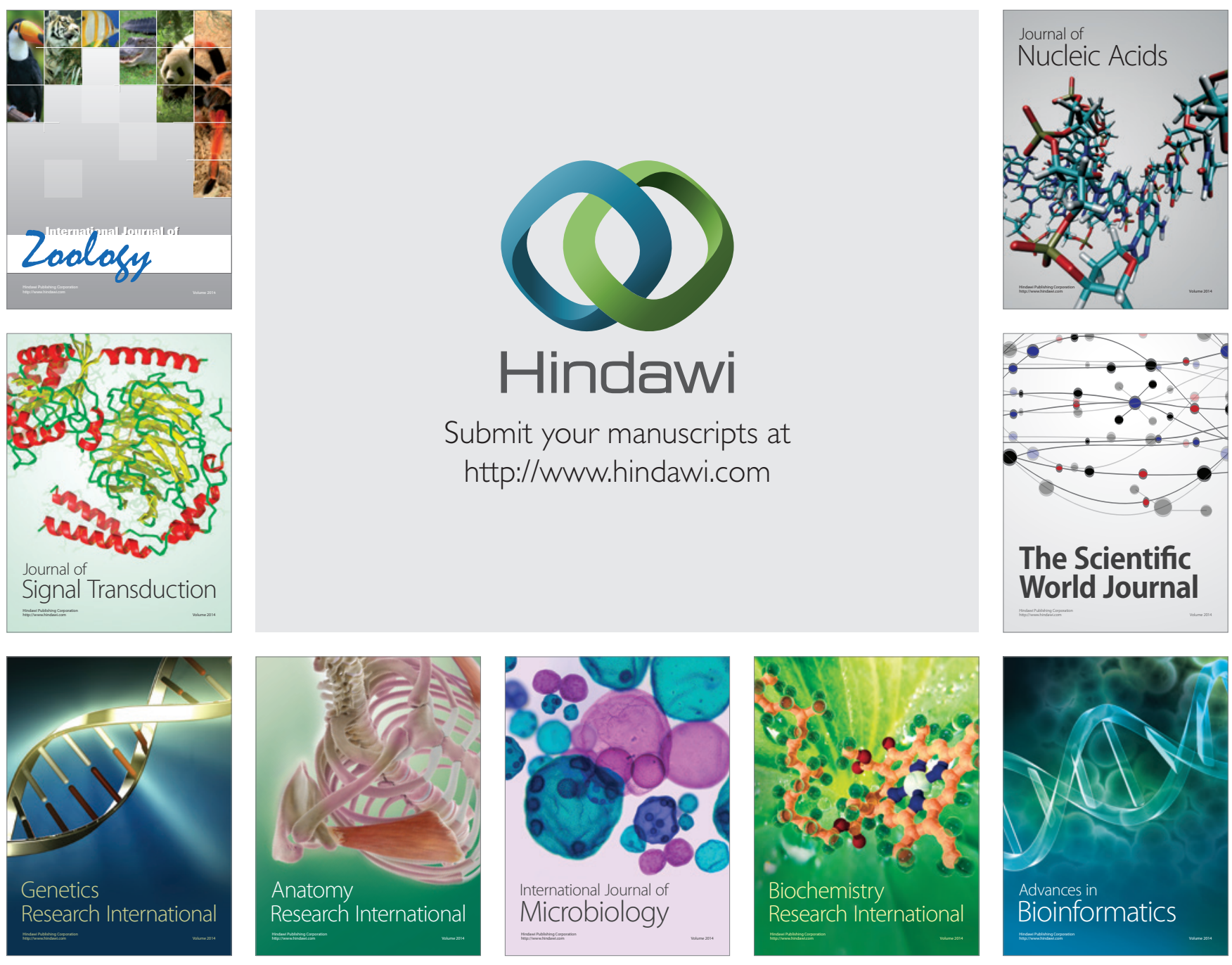

The Scientific World Journal
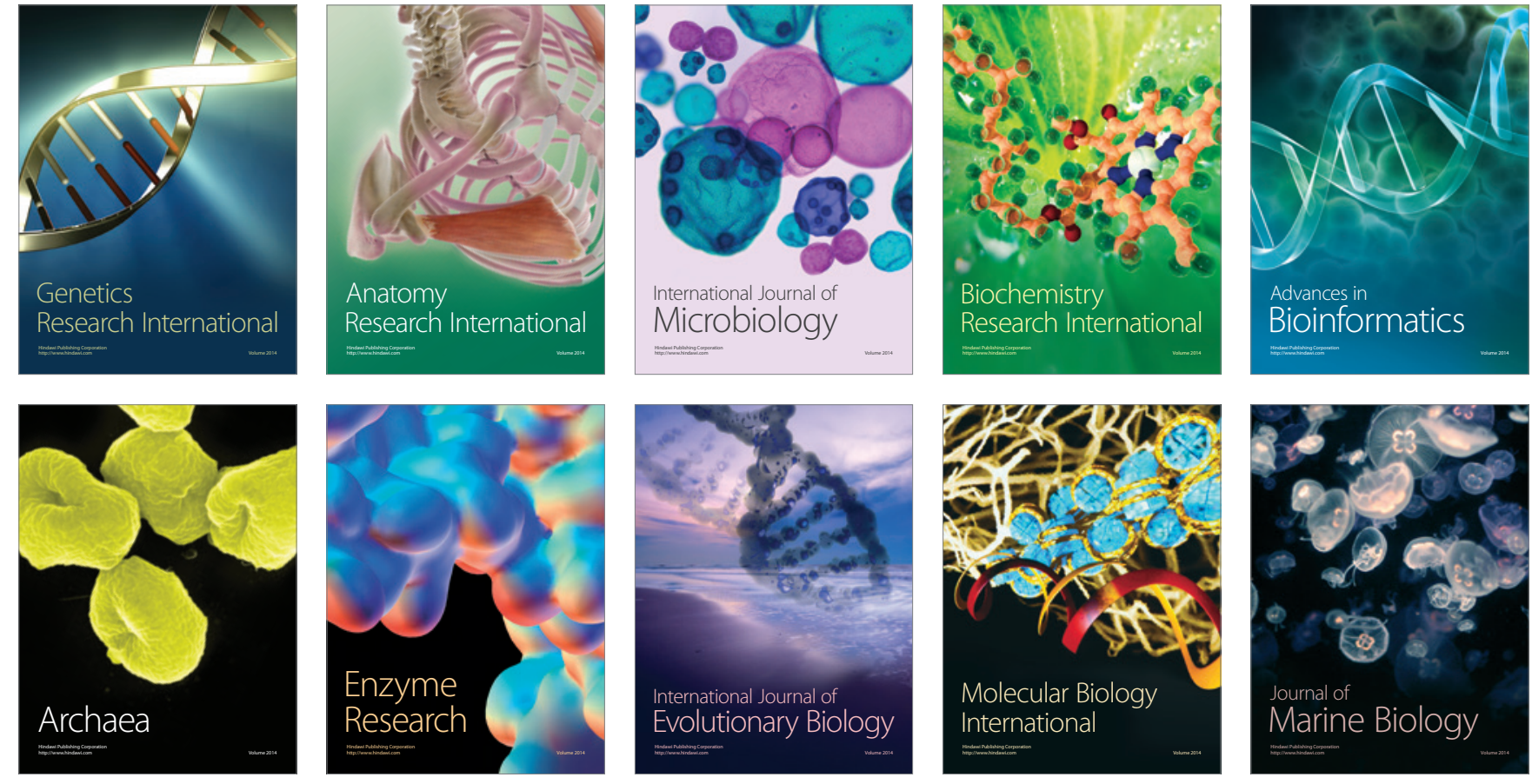